By ROBERT B. DOWNS

\title{
American Library Cooperation in Review
}

$\mathrm{F}^{\mathrm{OR}}$ Two or three generations American library leaders have been urging various types of joint effort. The potentialities of library cooperation are widely recognized and, for certain fields, accomplishments have been notable. In bibliographical enterprises, for example, no profession can point to finer cooperative achievements than Poole's Index, the Union List of Serials, the National Union Catalog in the Library of Congress, and similar undertakings successfully carried through by American librarians.

On the other hand, certain phases of library cooperation have made slight headway, though vigorously and convincingly promoted. Perhaps the time has come, therefore, for realistic stocktaking to see if we are proceeding on the right track and to determine as objectively as possible in what directions future efforts are likely to produce the most fruitful results. As a preliminary, an attempt will be made here to summarize the various kinds of cooperative arrangements developed to date, with some indication of their present status. ${ }^{1}$

\section{Union Lists}

Union lists have met with a more cordial reception than any other sort of library

1 Several previous "studies proved helpful in the preparation of this review, especially: Bishop, William Warner. "Resources of American Libraries." $\mathrm{Li}$. brary Quarterly 8:445-79, October 1938; Wilson, Louis Round. "Resources of Research Libraries: A Review." College and Research Libraries 5:259-66, June 1944; and a more general report, "Cooperation and Coordination in Higher Education." American Council on Education Studies, series 1, vol. 2, no. 5, April 1938 . cooperation, and it is not difficult to perceive the reasons why they have been prolific for the past seventy-five years. Such lists do not call for indefinite commitments on the part of the individual library, they do not require the library to give up anything, most of them are of immediate practical use, and it is a matter of considerable pride for the institution's holdings to be well represented. These factors have aided in the creation of monumental works like the Union List of Serials in Libraries of the United States and Canada, List of the Serial Publications of Foreign Governments, International Congresses and Conferences, I840-1937, American Newspapers, $1821-1936$, and Brigham's Bibliography of American Newspapers, $1600-1820$, not to mention hundreds of similar lists restricted to smaller regions and special subjects or types of material.

Union lists of books which have thus far appeared have been mainly concerned with large sets, early imprints, and specialized topics. Among recent examples are Stillwell's Incunabula in American Libraries, Bishop's Checklist of American Copies of "Short-Title Catalogue" Books, Thomson's "Monographic Holdings of American Libraries in the Medieval and Renaissance Fields,"2 Historical Records Survey's numerous publications in the American Imprints Inventory series, Emeneau's Union List of Printed Indic Texts and Translations in American Libraries, Gardner's Union List of Selected Western Books on

2 Progress of Medieval and Renaissance Studies, Bulletin $18: 28-52$, June 1944 . 
China, and Karpinski's Bibliography of Mathematical Works Printed in America Through 1850 . The manuscript field has not been neglected: extensive lists were issued by the Historical Records Survey, and there are more limited works, as Poleman's Census of Indic Manuscripts in the United States and Canada and De Ricci and Wilson's Census of Medieval and Renaissance Manuscripts in the United States and Canada. Obviously, the number of union lists pertaining to specialized subjects and categories of material can be, and is likely to be, expanded indefinitely. In fact, many are in preparation; an important instance is the checklist of about twelve thousand Russian titles in American libraries, now being compiled in the Library of Congress. The chief drawbacks to union lists of the character mentioned are the considerable expense to libraries in checking their holdings for inclusion, the fact that the lists soon go out of date and require revision, the small editions in which issued, and the danger of excessive multiplication of lists dealing with minute segments of knowledge.

\section{Union Catalogs}

Berthold's "Directory of Union Catalogs in the United States"3 records a total of I 7 catalogs now functioning in this country, divided among several principal types: national, regional, local, subject, exchange, and Library of Congress depository catalogs. The oldest of these, the National Union Catalog in Washington, dates from the beginning of the present century. Only one regional catalog, that of the California State Library, antedates 1930. The vast federal relief program of the I930's furnished the stimulus for dozens of new union catalogs-city, county, state, règional, exchange, and subject-widely distributed

\footnotetext{
3 Downs, Robert B., ed. Union Catalogs in the United States. Chicago, American Library Associa-
} tion, 1942, p. 351-91. over the nation. For several years a mass of free labor from federal government relief agencies was available for compiling catalogs. The gradual, and finally complete, withdrawal of this aid has placed some of the catalogs in a difficult financial position, forcing them to carry on with restricted budgets and staffs.

It would be a fair statement to say that most union catalog sponsors have not been particularly concerned with fitting their catalogs into any kind of national plan, and, consequently, some duplication of effort, questionable regional divisions, and other lack of integration are evident. A comprehensive survey of the union catalog situation was made in $1940-4 \mathrm{I}$ by a group of investigators under the sponsorship of the A.L.A. Board on Resources of American Libraries and was subsequently published. ${ }^{4}$ Recommendations were made therein for the future coordination and development of union catalogs, to insure thorough coverage of every portion of the country without needless overlapping and with due consideration to fiscal support.

Standing at the summit of our system of union catalogs is the great National Union Catalog in the Library of Congress. It is generally agreed that the maximum development and expansion of this catalog should be the primary objective of any union catalog program for the country. A committee of the Association of Research Libraries was appointed in 1942 to study ways and means of obtaining a full record for the National Union Catalog of all titles held by libraries in the United States. ${ }^{5}$ The committee came to the conclusion that publication in book form of the Catalog of Books Represented by Library of Congress Printed Cards offered a possible solution to the problem; approximately one hundred selected libraries

4 Op. cit.

5 Downs, Robert B. "Expanding the National Union Catalog." A.L.A. Bulletin 37:432-34, November i 943 . 
were asked to check volumes of the published depository catalog and to report any titles not recorded to the National Union Catalog. A favorable response to the proposal was received from a majority of libraries approached. By reason of difficult wartime conditions, especially labor shortages, the process of checking has not proceeded as rapidly as originally hoped for, although substantial contributions have been forwarded to Washington. A further step in the growth of the National Union Cata$\log$ is the incorporation of entries from the leading regional union catalogs. An appropriation from Congress in 1943 is making. possible the checking of the Cleveland and Philadelphia catalogs for this purpose, adding the holdings of hundreds of individual libraries. That we are far from the goal of a complete record in the National Union Catalog of all books in American libraries is strikingly demonstrated in LeRoy Merritt's study contained in Union Catalogs in the United States which, on the basis of extensive sampling, shows about four million titles thus far lacking.

\section{Bibliographical Centers}

Closely related to but broader in scope than the union catalog is the bibliographical center. The pioneer organization of this type is the Bibliographical Center for Research, Rocky Mountain Region, at Denver, which grew out of various experiments in library cooperation. Creation of the Denver center was begun in 1935, and since that time the development has been rapid. Thirteen institutions in Colorado, Wyoming, Utah, and New Mexico are now contributing financial support. The center's most basic tool is a union catalog, comprising a Library of Congress depository catalog, printed cards issued by John Crerar, Folger Library, and Princeton University, and records of holdings of some thirty libraries in the Rocky Mountain states-a total of $3,400,000$ cards. In addition, there is a collection of ten thousand volumes of national, trade, and subject bibliographies, library and sales catalogs, and several special card files. Present activities of the Denver bibliographical center fall into these main categories: location of books and other printed material, serving as a clearinghouse for interlibrary loans in the region, supplying cataloging data, and promoting cooperative book acquisition. Records show the center is being used constantly by a variety of persons, among them college faculty members and other teachers, students, businessmen, government officials, authors, and adult study groups. Over thirty thousand inquiries were received in I943, according to a recent report. ${ }^{6}$

Patterned after the Denver center are the Pacific Northwest Bibliographic Center at Seattle and the Philadelphia Bibliographical Center. The first is sponsored by the University of Washington and the second by the University of Pennsylvania. The resources, types of service, and general objectives are similar in all three centers. There is an unmistakable trend on the part of other union catalogs to expand and take on the functions of a bibliographical center, for they find, sooner or later, that their card files are insufficient to furnish the wide range of information for which they are called upon and they must develop other facilities in order to provide satisfactory services. Because of time and transportation factors and relatively inadequate collections for research in the Pacific Northwest and Rocky Mountain areas, the bibliographical centers in those regions are particularly vital, giving them resources far beyond the capacity of any single institution.

\section{Descriptions of Resources}

Another device for providing information

- The Bibliographical Center for Research, Rocky Mountain Region. (City Club Pamphlet, No. 27) Denver, 1944, p. 42. 
about library resources is descriptions of holdings. The first attempts of this nature were limited to lists of special collections, perhaps with brief notes, such as those by Johnston, Mudge, and Richardson. More recent examples have generally been planned on a broader scale, to cover resources as a whole, not simply special collections. They vary in comprehensiveness from reports on single libraries to surveys national in scope. Among the best of the guides to individual institutions are those for the New York Public Library, ${ }^{7}$ Harvard, ${ }^{8}$ University of Pennsylvania, ${ }^{9}$ and American Antiquarian Society. ${ }^{10}$ The same procedure has been applied to cities ${ }^{11}$ and to regions. ${ }^{12}$ In the city and regional studies all types of libraries and all important subject divisions represented were described. Several countrywide investigations covering a variety of fields have also been completed or are in process. These include the Joint Committee on Library Research Facilities for National Emergency's survey of materials in science and technology potentially useful for war purposes, ${ }^{13}$ and the Special Libraries Association's projected four-volume work, of

7 New York (City) Public Library. Guide to the Reference Collections of the Library. New York City, New York Public Library, 1941. 416p.

${ }_{8}$ Harvard University Library. Library of Harvard University. (Special Publications, 6) Cambridge, Harvard University Press, 1934. 186p.

9 Bibliographical Planning Committee of Philadelphia. Faculty Survey of the University of Pennsylvania Libraries. (Philadelphia Library Resources, No. I) Philadelphia, University of Pennsylvania Press, 1940. 202p.

${ }_{10}$ American , Antiquarian Society. Guide to the Resources of the Society. Worcester, The Society,

${ }_{11}^{1937}$ Downs, Robert B., ed. Resources of New York City Libraries. Chicago, American Library Association, I943; Library and Reference Facilities in the Area of the District of Columbia. Washington, Library of Congress, 1944. 95p.; Bibliographical Planning Committee of Philadelphia. Philadelphia Libraries and Their Holdings. Philadelphia, University of Pennsylvania Press, 1941. $46 \mathrm{p}$.

12 Downs, Robert B., ed. Resources of Southern Libraries. Chicago, American Library Association, 1938. 370p.; Van Male, John. Resources of Pacific Northwest Libraries. Seattle, Pacific Northwest Library Association, 1943. 404p.; Carlson, William H. "Library Resources in the Land of Little Water." "L.L.A. Bulletin 34:617-27, October 1940.

13 Joint Committee on Library Research Facilities for National Emergency. Guide to Library Facilities for National Defense, rev. ed., ed. by Carl L. Cannon. Chicago, American Library Association, 1941. 235p. which the first has been issued. ${ }^{14}$ An annual report on notable materials added to American libraries has appeared in the Library Quarterly, beginning with $1940 .{ }^{15}$ An attempt was also made simply to list, on the basis of opinions by specialists, the principal collections in libraries of the United States. ${ }^{16}$ From the point of view of the subject expert, surveys concentrating on limited fields are perhaps of greatest value, and the number of such studies is steadily increasing. ${ }^{17}$

The techniques followed in these various surveys of resources have differed widely. Some have depended entirely on questionnaires and correspondence, others on personal visits by outside investigators or local library staffs; most have followed careful plans, a few have developed haphazardly. Their usefulness to the research worker naturally varies in accordance with their completeness, the importance of libraries included, the amount of specific detail, the convenience of arrangement, and similar factors. The library resources survey should be regarded as complementary to the union catalog, neither taking the place of the other.

\section{Library Specialization or Division of Fields}

We come next to a type of library co-

14 Special Libraries Association. Special Library Resources, ed. by Rose L. Vormelker. New York City, Special Libraries Association, 1941. vol. I. $764 \mathrm{p}$.

${ }_{15}^{15}$ Library Quarterly 10:157-91, April 1940; $11: 257$ 301, July 1941; 12:175-220, April 1942; 14:132-58, April 1944.

16 Downs, Robert B. "Leading American Library Collections." Library Quarterly 12:457-73, July 1942

${ }^{17}$ Examples: Wilson, Louis R., and Downs, Robert B. "Special Collections for the Study of History and Literature in the Southeast." Papers of the Bibliographical Society of America 28:97.131, 1934; Gilder, Rosamond, and Freedley, George. Theatre Collections in Libraries and Museums. New York City Theatre Arts 1936. 182p.; Powell, Lawrence C. "Resources of irts 1936. 182p.; Powell, Lawrence C. "Resources Pacific Historical Review $11: 263-80$, September 1942 ; Carlson, William H. "Scandinavian Collections in the Libraries of the United States." Scandinavian Studies and Notes 15:217.38, August 1939: 16:201-303, November I94I; Poleman, Horace I "Facilities for Indic Studies in America." American Council of Learned Societies Bulletin, No. 28:27-107, May 1939; Hilton, Ronald, ed. Handbook of Hispanic Source Materials and Research Organizations in the United States. Toronto, University of Toronto Press, 1942. 441p. 
operation on which there is less general agreement than for any of the activities outlined above. From a practical point of view it is impossible for even the largest libraries, as they are now organized, to hold more than a fraction of the world's literature. Therefore, acquisition agreements among libraries would appear, theoretically at least, to be the logical and sensible solution. Nevertheless, a considerable amount of skepticism about the practicability of agreements for dividing collecting interests among libraries still prevails. Possibly Fremont Rider $^{18}$ has hit upon a fundamental weakness when he points out that the scholar is never reconciled to having his research materials in some other library, but insists on having them immediately at hand. Even Mr. Rider's microprint proposals, however, are based upon a high degree of specialization among libraries. Handicaps to library specialization were described further by Taube. ${ }^{19}$ The persistence of interest in the problem, however, is demonstrated by two special conferences, with published proceedings. ${ }^{20}$ The first of these, sponsored by the A.L.A. Board on Resources of American Libraries, discussed at length difficulties in the way of agreements but voted unanimous approval of a resolution on their desirability.

The latest contribution to the subject of specialization is the proposal of a committee of the Library of Congress Librarian's Council, composed of Keyes D. Metcalf, Archibald MacLeish, and Julian P. Boyd, ${ }^{21}$

18 Rider, Fremont. The Scholar and the Future of the Research Library. New York City, Hadham Press, 1944, p. $79-84$.

Taube, Mortimer. "The Realities of Library Specialization." Library Quarterly 12:246-56, April 1942.

$2 n$ A.L.A. Board on Resources of American Libraries. jerary Speci- ization; Proceedings of an Informal onferance. Chicago, American Library Association, 941. 48p.; "Proceedings of the Conference on Library Specialization;" "An Agreement for Regional Library, Specialization in the Pacific Northwest;" "Ap. pendix." PNLA Quarterly 8:52-59, January I944.

${ }_{21}$ Metcalf, Keyes D., and Williams, Edwin E.

"Proposal for a Division of Responsibility among Americen Libraries in the Acquisition and Recording of Library Materials." College and Research Libraries 5:105-05, March 1944. for a thorough coverage of the world's literature by American libraries. This would be accomplished by having cooperating institutions, each of which would have agreed to specialize in one or more given divisions of knowledge, acquire at least one copy of every book of potential research interest published anywhere in the world. The Library of Congress classification would be used as a basis for subject divisions. A second important step in the plan is to have every book thus obtained promptly listed in the National Union Catalog at the Library of Congress. Its sponsors realize their program cannot be placed in full effect until the war's end but are proceeding with preliminary details.

The library profession has a basis of experience extending over a considerable period of time for specialization agreements, though not on such an.ambitious scale as the Metcalf-MacLeish-Boyd proposal. In New York City, for example, an understanding between Columbia University and the New York Public Library dates back to 1896 ; certain fields are definitely allocated to one library or the other, and they consult with each other in the twilight zone not covered by this understanding. Working arrangements also prevail with more specialized institutions in the city. An extraordinarily effective program has also long existed among a group of Chicago libraries: John Crerar, Newberry, University of Chicago, and Chicago Public Library. The original plan became effective about I895; at that time the Newberry Library assumed responsibility for literature, history, and the arts, and John Crerar agreed to cover the natural, physical, and social sciences. Other assignments subsequently were made to the University of Chicago, Chicago Public Library, and other Chicago libraries. In the South one of the most noteworthy examples of library cooperation is that existing between Duke University 
and the University of North Carolina; ${ }^{22}$ included is a division of collecting interests for a number of subject fields, newspapers, and public documents. Another instance is in Nashville, Tenn., where Vanderbilt University, George Peabody College, and Scarritt College have worked out comprehensive plans for developing joint research collections as part of a far-reaching program of library cooperation. ${ }^{23}$

Numerous other illustrations could be cited of successful local agreements for sharing acquisition responsibilities. Of special interest are the following: the arrangement, begun about 1927, among the universities of Michigan and Minnesota, the John Crerar and Newberry libraries for purchasing cooperatively certain publications of European local academięs and societies; an understanding among the University of Minnesota, Minneapolis Public Library, Minnesota Historical Society, and Minneapolis Athenaeum in the fields of genealogy, local history, fine arts, music, and Scandinaviana; a similar agreement among Brown University Library and other libraries in Providence, for collecting local history, art, law, mathematics, Latin American literature, American poetry, Lincolniana, and state publications; a division in Cleveland among Western Reserve University, Cleveland Public Library, Western Reserve Historical Society, the Museum of Art, and the Natural History Museum; the centralization of order work for the six libraries of the Oregon State System of Higher Education $;{ }^{24}$ a division of the Latin American field among Duke

\footnotetext{
22 Downs, Robert B., and Branscomb, Harvie. "A Venture in University Library Cooperation." Library Journal 60:877-79, Nov. 15, 1935; Pratt, E. Carl. "Library Cooperation at Duke and North Carolina Universities." College and Research Libraries 2:142-45, March I94I.

${ }^{23} \mathrm{Kuhlman}, \mathrm{A}$. F., ed. Development of University Centers in the South. Nashville, Joint University Libraries, 1942 , p. $53^{-1} 28$.

24 Described in detail, along with various other types of library cooperation, in Mrs. Mildred $\mathrm{H}$. Lowell's College and University Library Consolidations. Eugene, Oregon State System, 1942. I36p.
}

University, University of North Carolina, and Tulane University; and an extensive cooperative program for preserving state and local newspapers undertaken by the University of Virginia, Virginia State Library, and some two dozen other Virginia libraries. Of a very specialized nature is the agreement among about thirty-four New England and New York libraries for the preservation of advertising sections of periodicals.

\section{Photographic Reproduction}

The widespread use of microfilm, beginning about a decade ago, has led to cooperative efforts of several kinds. It was realized early that establishment of a laboratory for film in every library would be uneconomical; hence, experts in the field have urged that a few fully-equipped laboratories be set up to serve a much larger number of libraries. The city-wide service provided by the University of Chicago Libraries' Department of Photographic Reproduction and by the American Documentation Institute's Bibliofilm Service, in Washington, are examples. On a commercial basis, University Microfilms of Ann Arbor, Mich., is performing in a similar manner. A coordination of microphotographic laboratories is under consideration for Philadelphia. ${ }^{25}$ Another step toward microfilm cooperation is directed toward making more generally available work already completed ; this was one of the purposes of a recent union list. ${ }^{26}$

The possibilities of cooperation in the reproduction of large, expensive works are virtually limitless. Among notable projects of that nature are the filming, for some sixteen libraries, of English books printad before 1550 , as listed in the Short Title

\footnotetext{
${ }^{25}$ Heilemann, J. J. "Coordination of Microphotographic Laboratories." Philadelphia Bibliographical Center. Documentation on a Regional Basis. Philadelphia, r 944, p. $25-26$.

${ }_{26}$ Philadelphia Bibliographical Center. Union List of Microfilms. Philadelphia, The Center. 1942. Sup. plement, 1943 .
} 
Catalogue; the microfilming of all extant magazines published in the continental United States before 1800 ; and the microprinting, in process, of the British Sessional Papers for the nineteenth century. Another is the reproduction by photo-offset of the Catalog of Books Represented by Library of Congress Printed Cards. It was recently reported that files of approximately I 50 major American newspapers are available in film form, and in a substantial number of cases the cost of filming was shared by two or more libraries. Before our entrance into the present war a project sponsored by Harvard University received a representative group of about fifty newspapers from the principal countries of the world and microfilmed them for distribution to American research libraries; war conditions have forced temporary suspension of the enterprise. Also dealing with a special type of material, the Library of Congress and the University of North Carolina Library jointly sent an operator with a microfilm camera to visit libraries throughout the country for the purpose of assembling a complete record of the proceedings of legislative bodies of the American colonies, territories, and states. Going far beyond these relatively limited undertakings is Fremont Rider's proposal to have each important research library become a publisher of microcards in fields assigned to it, the cards to be offered for sale to other libraries. ${ }^{27}$

\section{Cooperative Cataloging and Processing}

A cooperative cataloging project, under the sponsorship of the Library of Congress and the A.L.A. Cooperative Cataloging Committee, was initiated in 1932 , with the collaboration of libraries in the United States and Canada. During the ten-year period, 1933-43, the Library of Congress

${ }^{2}$ Rider, $o p$. cit., p. 176-209. received from cooperating libraries and edited card copy for about sixty thousand titles, chiefly new foreign books and monographs in scholarly series. It was recently reported ${ }^{28}$ that 365 libraries have cooperated in the contribution of titles for catalog entries which have been printed by the Library of Congress. In the same direction the Library of Congress has made arrangements with certain cooperating libraries by which each library is to supply catalog copy for the current official publications of its home state. The plan is to be gradually, extended to cover all states. In addition, libraries in several of the larger cities have agreed to catalog the official publications of their respective cities and to supply copy to the Library of Congress for printing. University libraries are being asked to furnish catalog copy for publications issued by their institutions, including doctoral dissertations and the products of university presses.

Another problem of increasing concern to our large research libraries is the huge accumulation of uncataloged materials, arrears from preceding years. A series of recommendations to meet the problem on a national scale was offered by Kellar. ${ }^{29} \mathrm{~A}$ plan for centralizing the cataloging of arrears has been suggested for the Philadelphia area $^{30}$ For the past three years a group of Colorado librarians has had under consideration an even more inclusive program, looking toward the possibility of centralizing technical processes for all types of libraries in the region. ${ }^{31}$

28 Library of Congress. Descriptive Cataloging Division. Cooperative Cataloging Manual for Use of Contributing Libraries. Washington, U.S. Government Printing Office, 1944, p. 50-60.

Printing Office, ${ }_{29}$ Kellar, Herbert A. $\mathrm{A}$. Memoranda on Library Cooperation. Washington, 1941, p. 18-29.

${ }_{90}$ Linderoth, Mrs. Kuth Witherbee. "Centralized Cataloging Project Philadelphia Bibliographical Center. Documentation on a Regional Basis. Philadelphia, 1944. p. 6-9.

31 Colorado College and Head Librarians Conference. "First Report of the Special Committee, Centralized Technical Processes and Bookbuying." August 1942; "Second Report," February 1943; "Planning Studies on Centralization." October $194^{2}$ (Mimeographed). 


\section{Duplicate Exchanges}

The system of exchanges for duplicate publications which the Medical Library Association has had in operation' since 1899 is generally acknowledged to be the most effective scheme thus far tried for disposing of such material. These are the essentials of the plan: lists of duplicates from all cooperating libraries are consolidated in a. central office, distributed to association members, and records of wants returned to the central office, with the larger libraries in the organization receiving priority for items available.

In 1940 a Periodical Exchange Union, limited to the problem of duplicate periodicals, was set up under the sponsorship of the Association of College and Reference Libraries. ${ }^{32}$. The procedure differs from the M.L.A. plan in several respects, chief of which is that lists of duplicates are circulated among the participating libraries in the order of the size of their annual budget for periodicals; libraries making the largest expenditures for periodicals have priority over others, on the theory that the material needed by them will be more rare and difficult to obtain.

An ingenious proposal for disposing of duplicate publications has been offered by Phineas Lawrence Windsor, of the University of Illinois, and others. The plan, in brief, is to box up duplicates, unlisted, and ship them to the nearest large library; the receiving library would select anything wanted, pass on the remainder to another library, and so on until everything was distributed or any residue could be discarded. Presumably, the duplicates would need to be roughly classified by subject or type under this scheme.

\footnotetext{
32 Van Deusen, Neil C. "Periodical Exchange Union." College and Research Libraries 2:288, June 1941. Name changed to Duplicate Exchange Union in 1944 and functions expanded. See Thompson, Donald E. "Duplicate Exchange Union." College and Re. search Libraries 6:158-60, March 1945.
}

\section{Central Storage Warehouses}

For the past forty-two years, since President Eliot of Harvard first advanced it, the idea of inexpensive centralized storage for little-used books has been discussed. Up to now, however, so far as the writer is aware, only one such cooperative storehouse has been constructed, namely the New England Deposit Library in Boston, serving Harvard University, Boston Public Library, Massachusetts Institute of Technology, and other institutions in the area. ${ }^{33}$ Economy of storage, elimination of duplication, and division of fields among libraries are primary objectives.

A central storage warehouse for the Midwest, with Chicago as a center, has been advocated for several years by President Hutchins, of the University of Chicago, and colleges of the Connecticut Valley have discussed central storage of large reference collections for the college libraries in the district. No concrete development has yet come from either proposal.

\section{Regional Library Development}

In several sections of the United States broad programs of regional library cooperation, embodying two or more of the specific types of cooperation outlined above, are under way or under consideration. The bibliographical centers of Denver and Seattle of course have aspects touching on many phases of regional cooperation. In the Atlanta-Athens area of Georgia, Emory University, Georgia School of Technology, University of Georgia, and other libraries have joined in a series of measures to improve and coordinate their resources. Recommendations for combining a group of North Texas institutions into a regional system for cooperative purposes were made by A. F. Kuhlman, on the basis of his

${ }^{33}$ Metcalf, Keyes D. "The New England Deposit Library." Library Quarterly $12: 622-28$, July 1942. 
survey of the situation there. ${ }^{34}$ Long-range plans for the development of university library centers in the South were discussed at a Nashville conference in $1944 .^{35}$

\section{Conclusion}

It is inevitable that lack of space and lack of information prevent mention of additional examples of, or proposals for, library cooperation which should be included in a complete record. A number of interesting plans are taking shape in the field of indexing and abstracting. The present status of the state document center program, inaugurated in 1930 , would be worth investigation for its bearing on questions of library integration. The problem of eliminating unwise competition among American libraries in postwar foreign book buying is a matter of concern now receiving particular attention from the Association of Research Libraries. Plans being formulated for extensive reprinting of publications originating

3 Kuhlman, A. F. The North Texas Regional Libraries; An Inquiry into the Feasibility and Desirability of Developing Them as a Cooperative Enterprise. Nashville, Tenn., George Peabody College Press, 1943. $85 \mathrm{p}$.

${ }_{35}$ Conference of Graduate Deans and Librarians, Nashville, Tenn. Development of Library Resources and Graduate Work in the Cooperative University Centers of the South, ed. by Philip G. Davidson and A. F. Kuhlman. Nashville, Joint University Libraries, 1944. 81p. in Axis-controlled countries will also involve the cooperation of research libraries. "The Checklist of Certain Periodicals" in scientific and technical fields published in enemy territory since 1939, a union list of American library holdings now being compiled in the Library of Congress, will provide a useful foundation for this purpose.

From a close study of accomplishments to date, there would appear to be certain important principles which have influenced the success or failure of various kinds of library cooperation. First, distance is a handicap, and it is easier for libraries not too far removed from each other to work together. Second, regional library cooperation has its greatest opportunities in those areas with inadequate book resources. Third, libraries should not be asked to give up anything but rather to assume positive responsibilities and receive direct benefits. Fourth, agreements must be flexible enough to provide for expansion and adjustment. Fifth, complete elimination of duplication between libraries is not possible or desirable. Finally, only a comparatively limited number of libraries are at present equipped to make any substantial or effective contribution to a general program of cooperation on the research level.

\section{Comment by Charles H. Brown}

\section{Union Catalogs and Problems of Collecting}

It is not easy to add to Mr. Downs's comprehensive inventory of cooperative projects in the field of librarianship nor to comment on most of them. One or two points, however, forced themselves upon the attention of at least one librarian, somewhat like the proverbial sore thumb.

We librarians have not made much progress in reaching understandings on acquisition policies. The reasons are obvious. Without affecting university policies, librarians can agree on union lists of serials, union catalogs, cooperative cataloging, and many other coopera- tive enterprises. When acquisition policies are concerned, our graduate colleges are immediately involved. So long as university administrators, deans of graduate colleges, and the faculties themselves do not realize the necessity for some agreement on the various fields of specialization in research which their universities should undertake, then the librarians can do little. Fortunately, there are indications that this need is beginning to receive more attention in university circles.

It certainly is more of a credit to an institution to have a few outstanding departments 
than to have many fields in which instruction is given on a mediocre scale. Many universities giving graduate instruction for the doctor's degree in the sciences do not have library facilities to support work in those disciplines. In a study now under way in the Iowa State College Library, the one hundred periodicals most frequently cited in representative journals in chemistry and botany were checked in the Union List of Serials. In chemistry only twenty to twenty-two institutions in the United States possessed three-fourths of these most-cited sets, although the study by the American Council on Education ${ }^{1}$ in 1934 would indicate that thirty-seven were qualified for instruction for the doctorate in chemistry. At present over sixty institutions are actually giving the doctor's degree in this field. In botany the study by the American Council would indicate that thirty institutions are considered qualified to give graduate work. Only about fifteen of these possess threefourths of the one hundred most-cited sets of periodicals in this field. Again, many other institutions not listed in the study by the American Council are attempting to give instruction for the doctorate in this field. Interlibrary loans, photostats, and films prove of some assistance, but no scientist wants to depend to a very considerable extent on interlibrary loans, much less on films and microprint. Indeed, for much scientific research, research publications must be available on the campus for frequent and extensive examination.

In the humanities conditions may be even worse. A university appoints a professor of history whose research is in the field of American colonial history. The librarian builds up a collection. In a few years the professor moves elsewhere, and the librarian is required to build up a research collection for a man specializing in the Civil War period. As yet, librarians are unwilling to adopt a proposal for the lending en bloc of publications more valuable elsewhere. Yet some of us are beginning to realize that the cost of storing large collections of little-used material is becoming an increasing burden and eventually will tax the resources of even our wealthiest institutions. Libraries in a given region will be

1 American Council on Education. Report of Com. mittee on Graduate Instruction. Washington, D.C., April 1934. compelled eventually to agree on certain areas in which they will collect exhaustively and other areas in which their acquisitions will be limited. It will be far better for us to attempt to work out some principles of cooperative acquisition for publications than to wait until some such policy is forced upon us by our administrators. Under the present system many libraries have attempted to cover so many fields that their collections have become inadequate for research in any field. Furthermore, this tendency to include something of everything, without any complete coverage in any field, has resulted in widespread duplication of publications rather easy to obtain and in a corresponding lack by all libraries in the United States of any copy of many publications which have been or may be urgently needed for research.

\section{Publications Not Available Elsewhere}

In view of the skepticism of librarians in regard to cooperative acquisition of publications, the Metcalf-MacLeish-Boyd committee wisely emphasized the need of acquiring publications which apparently are not available anywhere in the United States. As noted by $\mathrm{Mr}$. Downs, much progress has been achieved in certain fields of the humanities. No mention is made, however, of the need in certain fields of science. Some of us have found during the last few years that no copies of certain publications urgently needed for the war effort could be located in the United States. If these publications had appeared several hundred years ago, as in the case of the humanities, the lack would not create amazement, but no copy of many scientific publications published during the last forty years could be found anywhere in the United States. If the Metcalf-MacLeish-Boyd committee can provide for some checking of all publications of foreign countries to make sure that at least one copy is available in the United States, the committee will be rendering a service beyond measure to science and industry. If the committee had existed and been successful in its work in the prewar days, certain requests for material by our armed forces during the last few years would not have proved so embarrassing.

Librarians generally have developed their acquisitive tendencies to the extreme. The 
sole rule for accepting a book as a gift seems to be that it is one not already in the collection. It seems to make little difference whether some other library might be able to use the book to better advantage or not. It may be embarrassing to persuade a potential donor that books he wishes to give to one library might better be deposited in another.

The policy of accepting publications obtainable as gifts and buying without too much system has resulted in some situations which seem almost ludicrous. Many libraries have collections of German doctoral dissertations, all relatively easy to obtain, but when it comes to dissertations from universities in minor European countries, not one copy may be found anywhere in the United States. We have had no system for cooperative acquisition.

Without doubt, certain cities in this country are generously provided with research material. The various libraries in many cities have duplicate copies of publications which are little used, while in other sections of the country no copy can be found. Certainly research would be greatly stimulated by a redistribution of research publications on the basis of need, especially in view of the shortage of such publications, which is certain to become worse. The proposal to transfer certain collections which are duplicated in one city to other cities, or even to other countries, has more merit than appeared at first. Possibly microprint will eventually solve all of our problems, but the day for that does not appear to be at hand. A millennium has the habit of remaining at a distance when we attempt to approach it.

\section{Union Catalogs}

One more bit of heresy. Except for local use, the writer cannot see the reason for union catalogs, outside of the Library of Congress, in the regions east of the Mississippi. An air mail letter can reach the $\mathrm{Li}$ brary of Congress within twenty-four hours. We can obtain information as to the location of a book more satisfactorily from the $\mathrm{Na}$ tional Union Catalog of the Library of Congress than from any other source. Why write a center in Chicago, Cleveland, Cincinnati, or even Philadelphia, when more information can be obtained from the Library of Congress than from any of these cities? For the benefit of libraries in the immediate neighborhood of Chicago, a union catalog at Chicago might be of assistance, although it would be expensive. For most librarians, the union catalog of the Library of Congress will be the final recourse no matter what other union catalogs may be set up.

Comment by Keyes D. Metcalf

\section{Division of Fields of Collecting}

Mr. Downs's article is admirable in every particular-as a statement of fact and for its critical judgment about the adequacy and the practicability of what has been accomplished or proposed in the way of cooperation in the past. It is difficult to say more or to supplement what has already been said.

Three minor comments are submitted on the present situation, however. First, the Harvard foreign newspaper microfilm project is still going strong, although it has not been possible to keep up the microfilming of papers from parts of the world that were occupied by the totalitarian powers. Second, as a librarian in the Boston area, I am glad to go on record to the fact that the New England Deposit Library has been running along smoothly, financially and otherwise, in spite of the fact that lack of manual labor has made it impossible for libraries to send as much material to the deposit library as would have been the case in other times. It is expected that a second unit will be needed soon after the close of the war. And, third, it seems worth while to suggest that the critical point in cooperative cataloging lies in whether or not the Library of Congress or any other agency that might take its place can ever bring itself to accept cooperatively prepared copy without full revision. So far, alterations have cost more than they are worth. They have tended to hold back the whole cooperative cataloging program, which in the postwar period should be ready to expand greatly.

In addition to these comments, further con- 
sideration of division of fields seems called for. The research libraries of the country, as Mr. Rider explains so well in his book The Scholar and the Future of the Research Library, have been doubling on the average every sixteen to twenty years for generations. I am sure that Mr. Rider will agree that, after a library reaches a certain size and age, the rate of growth must stop. I am not ready to name the age, or to say whether the size is one, five, or ten million volumes. I might have said three million, since the New York Public Library, Harvard, and Yale have slowed up since reaching that figure, if I had not just finished reading the 1944 Annual Report of the Librarian of Congress telling of a net increase of 481,733 volumes in that library in one year. It seems evident, however, that the growth of libraries, like the rate of growth of anything else, whether it be that of an individual, the population of a country, the number of students in a university, or the size of ships, cannot increase indefinitely. The growth of libraries must slow down partly because of the lack of material to collect-it is impossible to believe that the number of books published will double every sixteen years indefinitely-but it must also slow down because the cost of building construction, of acquisition, of cataloging, and of service will at some point become so great that they will take more money than is available. The library in a university, for instance, cannot continue to increase its expenses more rapidly than other parts of the university without taking a larger and larger percentage of the total resources, and there is a limit as to how far a library can go in that way without becoming more of a nuisance than a blessing. When the time comes that the rate of growth must decrease and the library finds that it cannot continue to collect as extensively in all fields as in the past, it is suggested that there are at least four different courses of action that may be taken, as follows:

r. A library can definitely adopt the policy of becoming more selective in all fields. This is perfectly possible; but am I mistaken in believing that a library that is selective in all fields, and not really outstanding in any, may be a very good library but can never become a great library - a library with a country-wide reputation to which visiting scholars will come in large numbers, a library where productive research can be carried out on a large scale, a library that can be called truly outstanding?

2. A library may continue to try to do everything that it has done in the past but do it less and less well. It will then become overextended, the quality of its direct service to the public and of its cataloging and its collections will all decline, and it will become a Grade C or D library compared to others. It would not be difficult for any of us to think of a number of libraries that have become overextended, have tried to do more than they could with the funds that were made available to them, and have fallen down on the job. I am sure none of us wants to slide into that group deliberately if we can help it.

3. A library, when it finds that it cannot continue to keep up with its previous rate of growth, instead of trying to cover all its present fields might, for part of its work, fall back on interlibrary loan; on sending many of its advanced students to other libraries to find their material; on microfilm reproductions for particular items that are wanted; or, if Mr. Rider's dream comes true, on microcards. All of these throw the burden on someone else, while providing little or nothing in return, and sooner or later would result in an unbearable situation and a loss of reputation.

4. A library might finally go along with a division of fields, as proposed by the MetcalfMacLeish-Boyd committee and outlined in $\mathrm{Col}$ lege and Research Libraries for March $19444^{1}$ By this plan a library would become more selective in most fields but more inclusive than before in certain limited fields for which it agrees to assume responsibility and for which it will freely furnish books to others by interlibrary loan, by photographic reproduction, or by caring for visiting scholars, thus retaining its self-respect when it calls on other libraries for help.

Having lived with this plan for some months now, it is easy to see the objections to it. It is not going to be easy to organize on even a small scale. It is going to be very difficult to persuade libraries to reach the necessary agreements and, having reached them, to continue with them. There will be frequent complications when a university professor who has built up a strong collection dies or transfers to another university, with the result that his collection proves to be in

1 Metcalf, Keyes D., and Williams, Edwin E. "Proposal for a Division of Responsibility among American Libraries in the Acquisition and Recording of Library Materials." College and Research Libraries 5:105-09, March 1944. 
the wrong place for future use. It should be admitted that the plan is not a cure-all, but it will help when it comes to the specialized collections. It is these special collections that are most expensive to acquire, catalog, and maintain, but it is of first importance to have them somewhere in the country, and a cooperative program in connection with them seems desirable.

Note may properly be made here of progress in the above-mentioned committee's plans. The surveys of Belgian and Mexican publications have been completed; those for Sweden, Spain, and Peru are well under way; others will come along in due course. The results so far are enlightening. For Belgium it was found that 79 per cent of the titles selected from the 1937 lists as being of possible interest to research libraries cannot be found in any one of the fifty-five libraries that reported. ${ }^{\circ}$ These include practically all of the large general research libraries in the country. The total cost of all the priced items published in 1937 would have been only $\$ 1160$. That is, if one university library had been willing in the year 1937 to acquire all books of research importance published in the regular trade in Belgium in that year, it would have cost the institution only $\$ 1160$, and the other libraries of the country would have felt secure in their knowledge that they could be selective as far as Belgium was concerned, because all the material could be readily found elsewhere in the United States.

Comment by Raynard C. Swank

\section{Cooperative Subject Bibliography}

The librarian who reads Mr. Downs's article "American Library Cooperation in Review" may feel proud of the cooperative achievements of his profession; and, if he is a cataloger or a bibliographer, he may feel, as does this author, especially pleased that no field of library activity is more notably represented than the bibliographical. To union lists, union catalogs, bibliographical centers, descriptions of resources, and cooperative cataloging, more than half of Downs's review is devoted.

Yet these achievements represent for the most part but half the field of enumerative bibliography-that half which concerns the description and location of specified books or collections. The other half, which concerns the listing of books pertaining to specified subjects, is but meagerly represented. This omission is not an oversight. Indeed, it accurately reflects the present stage in a normal development of bibliographical enterprise.

The foundation upon which any system of subject bibliography must rest is patently the finding list. Unless books can be located, there is no point in seeking references to them in subject lists. That this foundation is already being well laid at the interlibrary level is evidenced by an impressive array of such cooperative works as the Union List of $\mathrm{Se}$ rials, American Newspapers, $1821-1936$, and the National Union Catalog in the Library of Congress. Yet it is equally patent that the finding list can never achieve its greatest usefulness without subject catalogs or bibliographies to supply references to books which subsequently need to be located. Provision for an adequate subject approach to library materials, also at the interlibrary level, is the indispensable next step in the development of a complete bibliographical system.

The librarian thus far has not altogether neglected this other half of the general bibliographical problem. The cooperative cataloging project, although primarily concerned with descriptive cataloging, aids in the assignment of subject headings for books entered in the card catalogs of individual libraries. But the subject catalog of the individual library complements the author catalog of that library only, not the union author catalog or the union list. As long as a person selects books from the subject catalog of one library, he will have no use for a finding list of books in other libraries. At the interlibrary plane a partial subject lead is offered by descriptions of the resources of various groups of libraries; but, valuable as these general descriptions are, they do not actually supply references to the materials on any subject. For lists of actual references to subject matter not contained in particular libraries, one must still depend 
wholly on pure subject bibliography-that heterogeneous mass of apparatus which has -been created primarily by the working scholar and which has not yet received the concentrated attention of the library profession.

The need of a more adequate subject approach to books has been sharply felt by many librarians in recent years. Proposals for the compilation of new union subject catalogs, in both card and book forms, have roused occasional discussion. This author, among others, has suggested greater emphasis in libraries on the compilation and exploitation of pure subject bibliographies. Striking out in another direction, Mr. Rider, who had previously advocated a plan for the publication of union dictionary catalogs, has now startled the library world with the possibilities of a microcard catalog, a major purpose of which would be the provision of a more effective subject approach to research materials.

The exact nature of the bibliographical system which may eventually best satisfy the subject needs of the reading public is anything but clear at this time. Indeed, the exact nature of the need itself is but vaguely known. There is still much, very much, to be learned about books and, especially, about readers before any comprehensive reorganization can be safely undertaken. Nevertheless, several basic propositions have already emerged in forms sufficiently clear to command the attention of every thoughtful librarian. If they are valid, as this author believes they are, the general character of future subject bibliography is indicated.

\section{Provision of Subject Approach}

1. The provision of an adequate subject approach to books is a general bibliographical problem, not merely a problem of library cataloging.

The library cataloger is and should be vitally interested in the matter, but he cannot readily solve it without reference to the experience and achievements of others who have long grappled with the same problem. Indeed, any proposal must be viewed with suspicion which does not account for the large amount of bibliographical activity apparent now, as always, among working scholars and professional bibliographers, as well as many librarians. No analysis can be sound which does not seek out the forces which reared such monumental works as the Cambridge Bibliography of English Literature, or which compel scholar after scholar to compile supplements, however clumsy, to such tools as Hammond's Chaucer manual, or which oblige readers advisers the country over to develop special lists and files of references found useful for different types of readers. On the other hand, any program which does not take into consideration the real values of library cataloging must also be viewed askance. This is not a matter for either the cataloger or the bibliographer alone; it is their common problem. And not until each gains an enlarged conception of the whole, a firmer grasp of the purposes and accomplishments of the other, and, above all, a more realistic awareness of actual needs-not until then can a satisfactory subject scheme be developed.

2. An adequate subject approach can be provided only by a system of special tools aimed directly at special needs, not by general tools aimed broadly at general needs.

One of the most disturbing elements in traditional cataloging thought has been the conviction that efficient service requires the general use of single, universal, subject tools for all readers. This shotgun method assumes a mass of average readers with unoriginal problems about stereotyped subjects. It assumes further a general unity of knowledge and a need in every reader to have all parts of that knowledge simultaneously at his fingertips. A more sensitive, discriminating method singles out comparatively small groups of readers, with fairly homogeneous needs, and then aims directly at them. For purely descriptive and locational purposes, the comprehensive, standardized, author tool may be altogether desirable, since books and their locations do not vary with readers' interests; but, for the selection of books to fit individual needs-and all needs are individual - the special approach is likely to be more rewarding than the general.

\section{Based on Value to Reader}

3. The selection of materials to be listed under subjects should be based on value to the reader, not on the incidence of materials in particular libraries or on the circumstances of publication.

The criteria which determine what is listed 
or not listed in many tools are manifold and confusing. In a large number of subject catalogs and indexes, as well as many "bibliographies," the material must first belong to the library, or libraries, or to the type of material being indexed. Second, it must to a large extent possess bibliographical independence - that is, it must consist of a separate work with its own title. Third, in many instances, it must appear in a prescribed physical form-a volume of so many pages, with or without boards, not on microfilm, or the like. Finally, then, if it still qualifies, it may be examined for relevance to subjects or readers' interest. But, meanwhile, a multitude of impertinent factors have so conditioned the results that no one can say precisely why this or that title appears or does not appear or precisely what need the list is capable of filling. From the point of view of the person who seeks references to guide his reading, such tools are low in bibliographical significance.

Significance, in this sense, is the fulness of meaning which a list holds for the reader, and the most significant list is the one about which it is possible to say, "Here are references to the materials-all the materials and nothing but the materials-relating to this subject and of value to this reader."

The tools which describe the subject content of libraries may obviously achieve high significance when that content itself is significant. There are special collections of which the catalogs approximate exhaustive bibliographies. There are also rigorously weeded collections of which the catalogs are valuable selective bibliographies. But most book collections are either too small to be exhaustive or too great to be selective, and no collection can be both. But, meanwhile, the limitations of no single collection, or group of collections, need be imposed upon subject lists and subsequently upon the reader. On the contrary, the subject list is the one device which can and should be used to help the reader, as well as the librarian, to surmount precisely those limitations.

\section{Subjects for Study}

4. The headings in subject lists should refer to subjects for study, not merely subjects of books.

In most existing subject tools, including library catalogs and many bibliographies, the headings point to the subjects of the books listed under them. Under "U.S.-HistoryColonial period," for example, are listed books about that period of American history. In other tools the headings represent, in a broader sense, subjects which the reader may wish to study. Under those headings are then listed not only materials which are, strictly speaking, about those subjects but also others which are necessary to the study of the subject. For example, under "U.S.-HistoryColonial period" might be listed, in addition to the histories about the period (i.e., the secondary sources), significant social and political works of the period (i.e., the primary sources). Or, for a student of The Dunciad, a catalog or bibliography might list under that heading the texts of the work itself and primary sources relating to its composition and publication-stationer's records, letters, etc.-as well as the history and criticism of the poem.

Books, in other words, may bear different relations to subjects, especially to literary, historical, and social subjects, and the list which places under a heading only the materials which are specifically about that subject may fail to guide the reader to other useful, if not essential, sources.

\section{"Subject-to-Book" Method}

5. Most effective in the compilation of subject lists is the "subject-to-book" process, not the "book-to-subject" process.

There are at least two different ways of compiling subject lists, and these are antithetic. The book-to-subject process is characteristic of library cataloging and indexing, wherein the compiler takes a book in hand and lists it under subjects where it may be found useful. As book after book is processed, the number of entries in all lists, or under all subjects, grows by accretion. The subjectto-book process is characteristic of "pure" subject bibliography, wherein the compiler takes a subject in hand and lists under it all books which may be found useful. As subject after subject is processed, the number of lists, instead of entries, grows by accretion.

Both methods have advantages, but those of the subject-to-book process seem the more important. First, the subject-to-book process offers a way of meeting important needs first, by dwelling on crucial subjects, letting others wait for time and circumstance. In the 
book-to-subject process, the controls relate primarily to forms of materials and the flow of new acquisitions into the library, often with the result that urgency goes begging. Second, the subject-to-book process brings the compiler into closer rapport with the library user. The compiler, like the reader, begins realistically with a specific problem and looks for books to solve it. His objective-to assemble useful books about a subject-is always clearly before him. In the book-tosubject process, the objective is too often simply to subject-head the book or to classify the library; and rarely does the compiler, who works at a distance from the reader, stop dispersing books among subjects long enough to see how meaningfully they are assembling on the other side. And, third, it is easier to circumscribe the books relating to a subject than the subjects to which a book may relate. Books are tangible objects which can be seized upon and analyzed for relevance to a definite need, but the needs themselves are as different as people and as intangible as the imagination. Many people know the literature of some subject, but few know all the needs which any book will satisfy.

It must be acknowledged, however, that the crude, preliminary sorting of books by subjects, as they first come from the press or the antiquarian's satchel, can take place only by the book-to-subject process. But this original subject indexing, whether done in library catalogs, in national or trade bibliographies, or elsewhere, is preparation only for the more intensive and critical work of the subject bibliographer.

\section{Character of System}

These propositions, if indeed they are valid, suggest the general character of the subject system which should be developed to complement the union author catalog or finding list. On the one hand, they militate against any effort to construct union subject catalogs or union dictionary catalogs analogous to the present catalogs of individual libraries. Such catalogs, as commonly conceived, would be general purpose tools based on the content of libraries and compiled by the book-to-subject process. On the other hand, they clearly support the possibility of enlarging and systematizing, in cooperation with scholars and bibliographers, the already indispensable resources of special subject bibliography.

The success of the subject portion of Mr. Rider's proposed microcard catalog would depend largely upon the selection of materials which can be published in that form. If, as he hopes, complete collections of the useful materials on special subjects can be issued, bibliographical significance would simultaneously be achieved. This might well come to pass if the process were begun with the compilation of adequate lists of materials on selected special subjects and then with the publication of microcards for all those materials.

The development of an adequate system of subject bibliography, whatever the form it takes, will require years of patient study and experiment. There are no short-cuts, no panaceas. First must come studies, not merely of books but of readers, and not merely of readers but of significant types of readers whose particular interests can be segregated and defined. These interests must then be translated into subjects, groups of subjects, and types of reading on those subjects. Then must come the search for books to fill those special needs and the publication of lists which can be recommended wherever those needs exist. For scholars in different fields there must be comprehensive bibliographies bearing directly on crucial problems and reflecting current theories and methods of research in those fields. For the farmer, the clubwoman, the industrial worker, the adolescent, or whoever else may display significantly different interests, there must be other lists, many of which may depart wholly from the academic subject categories of the scholar. Such an objective, to say the least, is ambitious and one not soon to be realized. But in the long view the results would be richly rewarding. And it is an objective which, if it is ever to be achieved, will exact the utmost of cooperative effort from librarians, scholars, and bibliographers alike. 